УДК 811.111'37'38'42(043.3)

DOI https://doi.org/10.26661/2414-1135-2021-83-13

\title{
ЛІНГВОРИТОРИКА ДІАЛОГУ В НАРАТИВІ: ІГРОВІ ЕФЕКТИ
}

\author{
Ізотова Н. П. \\ доктор філологічних наук, дочент, \\ професор кафедри англійської філологї̈, перекладу і філософії мови \\ імені професора О. М. Мороховського \\ Київський національний лінгвістичний університет \\ вул. Велика Васильківська, 73, Київ, Україна \\ orcid.org/0000-0003-2098-4687 \\ nat.izotova15@gmail.com
}

Ключові слова: діалогічний наратив; діалогічна гра, агональність, ігрова імітація, художне смислотворення, дейксис.
Дослідження спрямоване на розкриття лінгвориторичного аспекту функціонування діалогічних художніх форм у романах Дж.М. Кутзее "The Childhood of Jesus", "The Schooldays of Jesus" i "The Death of Jesus", розглянутих із позицій гри. Романи 3 трилогії про Ісуса становлять приклад діалогізованої художньої оповіді, тобто такого різновиду наративу, головним чинником розгортання якого $\epsilon$ не сюжетна канва, репрезентована сукупністю оповідних подій у їх індивідуальноавторському аранжуванні, а діалоги персонажів. Установлено, що діалогічний наратив у проаналізованих творах представлено трьома семантико-риторичними моделями діалогу - діалогом-поясненням, що охоплює низку наполегливих питань комунікатнів, націлених на з'ясування певних важливих моментів; діалогом-полемікою, що передбачає обговорення дискусійних питань, під час якого шляхом логічної аргументації співрозмовники намагаються переконати один одного в правильності власного підходу до цього питання; діалогомпротистоянням, який характеризується наявністю певного конфлікту, зіткненням протилежних поглядів і думок. Лінгвориторична специфіка діалогічної оповіді в трилогії Дж.М. Кутзее про Ісуса описана з опертям на два ігрові принципи - агональності й ігрової імітації сократівських діалогів, що простежуються під час розгортання діалогічного наративу в цих романах. Ігровий ефект смислового зіткнення як потенційний результат діалогічної гри-аргону та імітаційної гри виникає в досліджуваних діалогічних наративах завдяки семантиці суперечності та протистояння, що актуалізується у висловленнях головних героїв під час вирішення певного дискусійного питання. Діалогічні наративи, вплетені в сюжетно-композиційну структуру романів, сприяють іiі фрагментуванню. Водночас спільність теми/тем, що перебуває/перебувають у фокусі обговорення персонажів твору, навпаки, забезпечує семантичну єдність наративу, репрезентованого у формі діалогів. Лінгвориторика діалогу в аспекті оповідного тексто- та смислотворення в проаналізованих текстах розкрита із залученням інструментарію дейксису. 


\title{
LINGUISTIC RHETORIC OF DIALOGUE IN NARRATIVE: LUDIC EFFECTS
}

\author{
Izotova N. P. \\ Doctor of Science, Associate Professor, \\ Professor O. M Morokhovsky Department of English Philology, \\ Translation, and Philosophy of Language \\ Kyiv National Linguistic University \\ Velyka Vasylkivska str., 73, Kyiv, Ukraine \\ orcid.org/0000-0003-2098-4687 \\ nat.izotova15@gmail.com
}

Key words: dialogical narrative, dialogical game, agonality, ludic imitation, meaning-making, deixis.
This research addresses linguistic rhetoric of dialogical literary forms manifested in three novels authored by John Maxwell Coetzee - "The Childhood of Jesu", "The Schooldays of Jesus" and "The Death of Jesus". The paper adopts a ludic approach to interpreting the rhetorical features of such literary forms. Coetzee's Jesus trilogy can serve as an example of dialogicalized fictional narrative. This article argues that Coetzee's novels that make up the Jesus trilogy are dialogue-driven rather than plot-driven stories. A dialogue-driven narrative is a type of narrative in which the characters' conversations are the primary means of narrative advancement. The research findings show that in Coetzee's Jesus trilogy the dialogical narrative is manifested through three semantic and rhetorical models of the dialogue - explanatory dialogue, argumentative dialogue, and confrontational dialogue. The explanatory dialogue encompasses a number of tenacious questions aiming at clearing up important issues. The argumentative dialogue entails the discussion of debatable questions designed to convince the interlocutor of the correctness of one viewpoint over another by way of logical reasoning. In turn, the confrontational dialogue is based on a conflict thus highlighting a clash between opposing opinions. The paper reveals the rhetorical specificity of the dialogical narrative in Coetzee's Jesus trilogy with regard to two ludic principles - the agonal principle and the principle of ludic imitation of the Socratic dialogues. Dialogical gaming, both agonal and imitative, brings about the ludic effect of "semantic clash". Such effect is derived from the semantics of contradiction and disagreement embedded in the characters' statements that foreground a particular controversial issue. Inserted into the plot and composition structure of the novel, dialogical narratives cause its fragmentation. However, the semantic unity is provided by the thematic affinity achieved by the similarity of themes developed in the discussions of the characters. The research considers the linguistic rhetoric of dialogue in Coetzee's novels via a variety of deictic expressions and with regard to fictional meaning-making and text-building.
Постановка проблеми. Погляд на художній текст як певну «модель взаємодії автора й реципієнта» [1, с. 5] висуває на перший план інтенційно-рецептивну програму інтерпретації тексту, яка акцентує, з одного боку, комунікативну настанову автора художнього твору, а 3 іншого - запрограмовані в художньому тексті стратегії його прочитання.

Результати останніх філологічних розвідок досить переконливо доводять ефективність застосування ігрових стратегій для аналізу художнього дискурсу [2-6], зокрема, в лінгвориторичній перспективі [7]. Це пояснюється універсальністю й багатовимірністю гри, її евристичним характером, здатністю до розкриття креативних можливостей художніх форм та авторських риторико-художніх ідіосинказій [2-5]. При розгляді можливостей, які відкриває проектування гри на художні тексти, у центр уваги дослідника водночас потрапляють i сам процес моделювання художнього тексту в термінах гри, і результат, отриманий завдяки залученню гри в текст [8, с. 221].

Тлумачення риторики як галузі знань, що вивчає засоби та методи мовленнєвого впливу на аудиторію, способи відбору й репрезентації словесного матеріалу [9, с. 3; 10, с. 2538] в художньому оповідному тексті, підкреслює важливість дослідження тих риторичних прийомів 
у структурі художнього наративу, які впливають на його розуміння та інтерпретацію.

Матеріалом розвідки слугують три романи Дж.М. Кутзее "The Childhood of Jesus" («Дитинство Iсуса»), “The Schooldays of Jesus” («Шкільні роки Iсуса») i "The Death of Jesus" («Смерть Ісуса»), де ключовим мовно-риторичним прийомом можна вважати діалогізацію художньої оповіді, що розгортається за принципами гри.

Актуальність статті визначається загальною зосередженістю новітніх лінгвориторичних і лінгводидактичних студій на вивченні лінгвориторичних принципів побудови різножанрових художніх текстів і розробці ефективних методологічних засад аналізу таких текстів, зокрема, із застосуванням інструментарію гри.

Мета й завдання статті. Мета дослідження полягає в розкритті лінгвориторичної специфіки діалогів, репрезентованих у трилогії Дж.М. Кутзее про Ісуса. Досягнення поставленої мети передбачає вирішення таких ключових завдань: 1) окреслити ідіожанрові риси зазначених художніх творів письменника; 2) систематизувати підходи до розуміння феномена діалогічності в художньому тексті; 3) дати визначення поняття «діалогізований художній наратив» у контексті інтерпретації романів "The Childhood of Jesus", "The Schooldays of Jesus" та "The Death of Jesus"; 4) побудувати й описати лінгвориторичні моделі діалогів у досліджуваних творах Дж.М. Кутзее; 5) виявити ігрові ефекти, що виникають під час розгортання діалогічної комунікації, уписаної в романи Дж.М. Кутзее, що становлять трилогію про Iсуса.

Предмет та об'скт дослідження. Предметом наукової розвідки слугують діалогічні наративи, утілені в романах Дж. М. Кутзее "The Childhood of Jesus", "The Schooldays of Jesus" i "The Death of Jesus"; об'єктом вивчення є лінгвориторичний аспект діалогічних наративів у зазначених творах Дж.М. Кутзее, розглянутий 3 опертям на принципи гри.

Виклад основного матеріалу дослідження. Романам Дж.М. Кутзее "The Childhood of Jesus", "The Schooldays of Jesus" i "The Death of Jesus", що належать до періоду пізньої творчості письменника, притаманна стійка тенденція до філософізації художньої форми. Його твори набувають рис філософського наративу, що тлумачиться як наратив про роздуми, про конструювання думки $[11$, с. 10]. Це оповідь, що фокусується на процесі пошуку та експлікації персонажами різних думок та/або ідей, що в наративі становлять, з одного боку, предмет зображення [12, с. 38], а з іншого домінанту побудови образів персонажів [12, с. 36]. У структурному плані філософський наратив $є$ мережею «епізодів» [11, с. 10], задіяних у вибудо- вуванні кожним персонажем власної думки та/або породженні ідеї.

3 огляду на те що формою репрезентації філософського наративу в досліджуваних творах Дж.М. Кутзее є діалог, така оповідь постає як діалогізований філософський художній наратив. Варто зазначити, що в романах Дж.М. Кутзее загалом зустрічаються різні за формою діалоги $[13$, с. 151$]$, граючи $з$ якими автор апробує можливості діалогічних оповідних форм.

Нагадаємо, що під діалогізацією художнього наративу дослідники розуміють три відмінні процеси [12, с. 5-69; 14, с. 7-9]. По-перше, вона передбачає встановлення діалогічних стосунків між суб'єктами художньої комунікації - автором і читачем; по-друге, діалогізація пов'язується 3 реалізацією міжтекстових діалогічних зв'язків; по-третє, діалогізація грунтується на актуалізації діалогічних стосунків між персонажами художньої оповіді.

У дослідженні під діалогізованою художньою оповіддю маємо на увазі різновид наративу, головним рушієм розгортання якого $є$ не сюжет, репрезентований сукупністю оповідних подій у їх індивідуально-авторському аранжуванні, а діалоги персонажів. Отже, діалогізований художній наратив структурується переважно діалогами персонажів, і розуміння такого типу оповіді зумовлюється мовленнєвими партіями учасників діалогу/ діалогів (персонажів) як носіїв певних текстових смислів, що стоять за предметом їх обговорення.

Діалог із лінгвістичних позицій трактується як функціональний різновид мовлення (тип комунікації, принцип організації комунікації), який створює текст особливого типу [15, с. 8], або як засіб передачі логічного ланцюжка змістовно взаємопов'язаних думок-суджень, мовленнєва конструкція, у якій мовці вдвох розгортають одну думку, структура, де тема розподіляється між двома співрозмовниками [16, с. 299-313].

Основними диференційними ознаками діалогу дослідники вважають дискретність (властивість видавати інформацію порціями) [12, с. 207], асиметричність, яка, по-перше, відображається в розбіжностях семіотичної структури (мовлення) учасників діалогу, а по-друге, - у почерговій скерованості повідомлень [17, с. 206], наявність не менше двох співрозмовників [15, с. 8], взаємну зачікавленість комунікантів у повідомленні та ї спроможність усунути бар'єри в комунікації [17, с. 206], позитивний $і$ конструктивний підхід до врегулювання конкретної проблемної ситуації $[18$, c. 455$]$.

У філософських романах Дж.М. Кутзее, які іноді називають наративами ідей [13, с. 153; 19 , с. $3 ; 20$, с. 169], думки викладаються не просто як аргументи чи висловлення [20, с. 182]. 
Тут оповідь набирає форми дебатів персонажів iз протилежними поглядами, опонентів, які словесно втілюють мотив протистояння [20, с. 167], репрезентуючи новий спосіб інтегрування частин художньої оповіді в єдине ціле - агональний. Граагон, за роз'ясненням Й. Хейзінги, - це гра-змагання [21, с. 84], фінальний результат якої полягає не стільки в досягненні певної мети, скільки в самому процесі [20, с. 167]. Ігровий ефект смислового зіткнення [3], що становить потенційний результат діалогічної гри-аргону в досліджуваних романах Дж.М. Кутзее, виникає завдяки семантиці суперечності й зіставлення, що простежується у висловленнях головних героїв під час вирішення певного дискусійного питання.

Аналіз матеріалу дав змогу виокремити як основні три семантико-риторичні моделі діалогів - діалог-пояснення, діалог-полеміку та діалог-протистояння, у яких ідентифікується агональність. Розглянемо їх докладніше.

Діалог-пояснення - це діалог, у якому один із комунікантів випробовує іншого шляхом наполегливих питань, намагаючись дізнатися щось цікаве й важливе для себе [22, с. 107]. Наприклад:

'Can you give me some clue, some fingerhold?', he says. 'I want to understand. Genuinely. I genuinely wish to understand.'

Seňor Arroyo speaks. 'You wish to understand. You address me as if you I were the sage of Estrella, the man with all the answers. I am not. I do not have answers for you. But let me say a word about answers in general. I my opinion, question and answers go together like heaven and earth or like man and woman. A man goes out and scours the world for answers to his one great question, What is it that I lack? Then one day, if he is lucky, he finds his answers: woman. Man and woman come together, they are one - let us resort to that expression - and out of their oneness, their union, come a child. The child grows up until one day the question comes to him, What is it that I lack?, and so the cycle is resumed. The cycle resumes because in the question already lies the answer, like an unborn child'.

'Therefore?'

'Therefore, if we wish to escape the cycle, perhaps we should be scouring the world not for the true answer but for the true question. Perhaps that is what we lack.[29, p. 96].

Співрозмовники наведеного діалогу-пояснення - це персонажі роману "The Schooldays of Jesus": Симон, який опікується маленьким Давидом, і сеньйор Арройо - учитель музики в Академії танцю, де навчається хлопчик. Варто зазначити, що Академія танцю є досить незвичним навчальним закладом, адже викладання предметів, навіть математики, відбувається тут за допомогою танців. У цьому діалозі Симон хоче 3'ясувати для себе особливості системи навчання в Академії, звертається із цим питанням до сеньйора Арройо (Can you give me some clue, some fingerhold). Однак учитель не дає чіткої відповіді на запитання, натомість починає дискусію про те, що кожна відповідь здатна породжувати нові питання, а як наслідок - утворюється замкнене коло (The cycle resumes). На думку сеньйора Арройо, уникнути замкненого кола можна лише за умови, що питання, які ставляться, правильні (the true question).

Діалог-полеміка передбачає обговорення дискусійних питань, під час якого шляхом логічної аргументації співрозмовники намагаються переконати один одного в правильності власного підходу до цього питання. Наприклад:

"Why are we so sure we need to be saved, Simón?Do you think we live the lives of stevedores because we have been found too stupid to do anything else - too stupid to assemble a pump or drive a car. [...]. This is our dock, our wharf - right? He glances left and right; the men murmur their approval. 'There is no place for cleverness here, only for the thing itself." [...]

"Listen to yourself, Alvaro', he says. 'The thing itself. Do you think the things remains forever itself, unchanging? No. Everything flows. Did you forget that when you crossed the ocean to come here? The waters of the ocean flow and in flowing they change. You cannot step twice into the same waters. As the fish live in the sea, so we live in tome and must change with time. No matter how firmly we may pledge ourselves to follow the venerable traditions of stevedoring, we will in the end be overtaken by change. Change is like rising tide. You can build barriers, but it will always seep in through the chinks" [28, p. 114-115].

Агональність наведеного діалогу-полеміки як підгрунтя реалізації тут діалогічної гри ідентифікується з огляду на намагання Симона, головного героя роману "The Childhood of Jesus", переконати людей, спільно з якими він працює в порту, оптимізувати роботу, для чого, скажімо, замість коней і візків, застосувати вантажівки, а також покласти край практиці зберігання зерна на складі, адже там багато щурів, тощо. Тобто Симон спонукає своїх колег до певних змін. Щоб його слова були почуті, він підкреслює неминучість змін у житті кожної людини і звертається до метафори води в океані, яка весь час змінюється, ніколи не лишаючись однаковою (The waters of the ocean flow and in flowing they change).

Діалог-протистояння визначається наявністю певного конфлікту, зіткнення протилежних поглядів і думок. Наприклад:

"Are you sure you have done the right thing, giving your child away to a woman like that?"

"To a woman with a dog?" 
"To a childless woman in her thirties. A woman who spends her time playing sports with men. A woman who keeps dogs."

"Inés plays tennis. Lots of women play tennis. It's enjoyable. It keeps you fit. And she has only one dog."

"Has she told you anything about her background, her past?"

"No. I didn't ask her."

"Well, in my opinion you are out of mind, handling over your child to a stranger who all you know has a dubious past."

"That's nonsense, Elena. Inés has no past, none that counts. None of us has a past. We start anew here. We start with a blank slate, a virgin slate. And Inés is not a stranger. I recognized her as soon as I set eyes on her, which means I must have some kind of prior knowledge" [28, p. 97-98].

У наведеній ілюстрації діалогу-протистояння 3 роману Дж.М. Кутзее "The Childhood of Jesus" актуалізовано конфлікт між двома персонажами - Симоном і його доброю знайомою Еленою - у питанні щодо правильності вибору усиновительки для маленького Давида. Елена аргументує своє негативне ставлення до вибору на цю роль Інес - жінки, яка їм трапилася в одному 3 районів Новілли, оскільки іiі минуле викликає сумніви (to a stranger who all you know has a dubious past), адже в Інес, хоч ій уже за тридцять, досі немає дітей (a childless woman in her thirties), вона грає в теніс із чоловіками (A woman who spends her time playing sports with men) і має собаку (a woman with a dog). Ідіоматичними виразами to be out of mind 3 оцінною семантикою ('to be stupid('дypний, безглуздий') i 'to be crazy('божевільний') [23, с. 1044]) експлікується негативне ставлення Елени до Інес. Проте реакція Симона на такі міркування емоційно несхвальна, про що свідчить ужитий ним іменник nonsense, який характеризує iii аргументи як безглузді ('stupid[23, c. 1116]) i помилкові ('untrue[23, с. 1116]).

Крім принципу агональності, у діалогізованих наративах Дж.М. Кутзее простежується ігровий принцип імітації, адже в основу правил ведення діалогів у романах "The Childhood of Jesus", "The Schooldays of Jesus" $i$ "The Death of Jesus" покладено принципи сократівського діалогу $[13$, с. $151 ; 19]$.

Спільними для діалогів Сократа [24, с. 179-181] і Дж.М. Кутзее [13, с. 151-173; 25, с. 86-90] є їx багатоголосся (тобто участь у діалозі різних, але рівноправних голосів), дослідницька (визначення співрозмовниками понять, що стосуються об'єкта обговорення, виокремлення й коментування його істотних властивостей) і пошукова (під час вільного обміну думками між співрозмовники відбувається пошук протиріч) природа. Водночас, на відміну від сократівських діалогів, яким властиве виявлення й усунення в процесі обговорення всіх протиріч [24, с. 179-181], у діалогах персонажів романів Дж.М. Кутзее суперечності, навпаки, висуваються на перший план [13, с. 161].

Одиницею діалогізованого наративу, представленого в текстах досліджуваних романів Дж.М. Кутзее, слідом за В.І. Лагутіним [15, с. 15], уважаємо діалогічну репліку, яка, розвиваючи певну тему та/або ідею, експлікує ставлення мовця до предмета обговорення. Сукупність діалогічних реплік, сфокусованих довкола однієї теми, формує тематичний смисловий блок $[15$, с. 71$]$ як фрагмент тексту, який об'єднаний однією темою та такий, що характеризується єдністю референції предмета обговорення в конкретному уривку тексту [15, с. 71].

Якщо діалогізація художньої оповіді загалом призводить до роздроблення, фрагментування сюжетно-композиційної площини художнього наративу, то спільність теми/тем, що перебуває/ перебувають у фокусі обговорення персонажів твору, навпаки, забезпечує семантичну єдність наративу, репрезентованого у формі діалогів.

Ігрове моделювання філософського діалогізованого наративу в романах "The Childhood of Jesus", "The Schooldays of Jesus" i "The Death of Jesus" уможливлюється завдяки опорі на дейксис, який дає змогу «ідентифікацію суб'єктів та об'єктів» через їх ставлення до мовленнєвої ситуації [26, с. 286]. Відповідно, динаміка оповідного смислотворення, організованого за принципом гри-імітації сократівського діалогу, відстежується в романах Дж.М. Кутзее завдяки використанню сукупності мовленнєвих засобів експлікації ставлення мовця до предмета обговорення (мовлення), адресата, а також інших учасників діалогічної комунікації [11, с. 3$]$.

Оскільки в основу діалогів персонажів художнього твору закладені їх точки зору, можна твердити, що семантика діалогізованої художньої оповіді об'єктивується тими смислами, які стоять за певною точкою зору. 3 огляду на те, що у двох останніх романах Дж.М. Кутзее досліджує багато тем, які іноді перегукуються з темами попередніх творів автора, виникає поняття «музей кутзеєвських тем» [27, с. 196]. Наскрізними темами в "The Childhood of Jesus", "The Schooldays of Jesus" $i$ "The Death of Jesus" $€$ такі: 1) стосунки між батьками і дітьми в сім'і; 2) питання виховання та освіти; 3) проблеми міграції та адаптації мігрантів до життя в новій країні тощо. Наприклад:

But the boy is not sleepy. "What are we here for, Simón?" he asks quietly.

"I told you: we are here just for a night or two, till we find a better place to stay."

"No, I mean, why are we here?" His gesture takes in the room, the Centre, the city of Novilla, everything. 
"You are here to find your mother. I am here to help you."

"But after we find her, what are we here for?"

"I don't know what to say. We are here for the same reason everyone else is. We have been given a chance to live and we have accepted that chance. It is a great thing, to live. It is the greatest thing of all", [28, p. 17].

Наведений текст $\epsilon$ діалогом-поясненням, у якому увага приділена темі соціальної міграції. Головний герой роману "The Childhood of Jesus" Симон сприймає міграцію як шанс на виживання (We have been given a chance to live). Лінгвостилістичним засобом експлікації його погляду на можливість переїзду в іншу країну слугують лексичні повтори ключових слів (a chance, that chance; a great thing, the greatest thing), цей художній прийом доповнює анафорично вжитий прийом градації, у сукупності ці стилістичні засоби значно підсилюють переконливість пояснення Симона.

Висновки й перспективи подальших розробок у цьому напрямі. Таким чином, завдяки діалогічній грі в романах Дж.М. Кутзее, що грунтується на принципах агональності й ігрової імітації сократівських діалогів, відбувається інноваційна трансформація художньої оповіді, спрямованої на подію, де подія є основним чинником розгортання сюжету наративу, до наративу, орієнтованого на ідею, у якому сюжет розгортається шляхом діалогічного конструювання (вибудовування) персонажами певних думок i/або ідей. Тексто- та смислопобудова діалогізованого наративу в проаналізованих романах відбита в трьох риторичних індивідуально-авторських моделях діалогу - діалозі-поясненні, діалозі-полеміці, діалозі-протистоянні. Перспективи подальших розвідок у цьому напрямі вбачаємо в розробці лінгвокогнітивних стратегій прочитання різножанрових текстів з урахуванням їх ідіожанрових рис і $з$ опертям на принципи гра.

\section{ЛІТЕРАТУРА}

1. Чепелєва Н.В. Текст і читач : посібник. Житомир : Вид-во ЖДУ імені І. Франка, 2015. 124 с.

2. Гридина Т.А. Языковая игра в художественном тексте : монография. Екатеринбург : Урал. гос. пед. ун-т, 2008. 156 с.

3. Ізотова Н.П. Лінгвонаратологія ігрових художніх форм: ідіожанровий аспект. Вісник КНЛУ. 2020. Вип. 23. № 2. С. 47-57.

4. Люксембург А.М. Амбивалентность как свойство набоковской игровой поэтики. Научно-культурологический журнал. 1999. № 15 (21). URL: http://www.relga.ru/Environ/ WebObjects/tgu-www.woa/wa/Main?textid=16 94\&level1=main\&level2= articles (дата звернення: 14.08.2021).
5. Радзієвська Т.В. Мовна особистість, мовна гра, лінгвістичні концепти крізь призму роману B.B. Набокова «The Real Life of Sebastian Knight». Вісник КНЛУ. 2014. Т. 17. № 1. C. 146-155.

6. Chrzanowska-Kluczewska E. Language games: pro and against. Krakow : Universitas, 2004. 220 p.

7. Booth W.C. The rhetoric of fiction $/ 2^{\text {nd }}$ edit. Chicago \& London : The University of Chicago Press, 1983. 552 p.

8. Абиева Н.А. Игровая стратегия построения нарратива в электронном художественном тексте. Логический анализ языка. Кониептуальные поля игры / отв. ред. Н.Д. Арутюнова. Москва : Индрик, 2006. С. 206-234.

9. Никитина Е.А. Риторические приемы повествования : монография. Елецк : Изд-во Елец. гос. универ. им. И.А. Бунина, 2016. 111 с.

10. Vorozhbitova A.A., Potapenko S.I. Linguistic $\&$ rhetorical paradigm as innovative theoretical methodological platform of studying discursive processes of East Slavic and Western cultures. European Researcher. 2013. Vol. 61. № 10-2. C. 2536-2543.

11. Гейченко С.А. Повествовательная структура русского философского текста: лингвистика нарратива (на материале сочинений П.А. Флоренского и А.Ф. Лосева) : автореф. дисс. ... канд. филол. наук : 10.02.01. Москва, 2013. 29 с.

12. Бахтин М.М. Проблемы поэтики Достоевского. Санкт-Петербур : Азбука, 2015. 416 с.

13. Wilm J. The Slow Philosophy of J. M. Coetzee. London : Bloomsbury, 2016. 251 p.

14. Скорик К.В. Диалогизация художественного текста: типы и способы ее актуализации в англоязычной прозе : автореф. дисс. ... канд. филол. наук : 10.02.04. Санкт-Петербург, 2010. 19 c.

15. Лагутин В.И. Проблемы анализа художественного диалога : монография. Кишинев : Штиинца, 1991. 99 с.

16. Валюсинская 3.В. Вопросы изучения диалога в работах советских лингвистов. Синтаксис текста. Москва : Наука, 1979. С. 299-313.

17. Лотман Ю.М. Механизмы диалога. Лотман Ю.М. Внутри мыслящих миров. Санкт-Петербург : Азбука, Азбука-Аттикус, 2015. С. 206-219.

18. Гиршман М. Диалог и художественная целостность. Литературное произведение: Теория художественной иелостности / 2-е изд., доп. Москва : Языки славянских культур, 2007. C. 451-545.

19. Rutherford J., Uhlmann A. Introduction. J. Coetzee's The Childhood of Jesus: The ethics 
of ideas and things / ed. by J. Rutherford and A. Uhlmann. New York : Bloomsbury, 2017. P. 3-5.

20. Mehigan T. Coetzee's The Childhood of Jesus and the Moral Image of the World. J. Coetzee's The Childhood of Jesus: The ethics of ideas and things / ed. by J. Rutherford and A. Uhlmann. New York : Bloomsbury, 2017. P. 165-186.

21. Хейзинга Й. Нomo ludens. Человек играющий / сост., предисл. и пер. с нидерланд. Д.В. Сельвестрова ; коммент., указатель Д.Э. Харитоновича. Санкт-Петербург : Изд. Ивана Лимбаха, 2011. 416 c.

22. Соловьева А.К. О некоторых общих вопросах диалога. Bопросы языкознания. 1965. № 6. C. $104-110$.

23. Longman Dictionary of Contemporary English: $4^{\text {th }}$ ed. London, New York : Longman, 2005. 1950 p.

24. Рапацевич Е.С. Психолого-педагогический словарь. Минск : Современное слово, 2006. $928 \mathrm{c}$.

25. Ng L., Sheehan P. Coetzee's Republic: Plato, Borges and Migrant Memory in The Childhood of Jesus. J. Coetzee's The Childhood of Jesus: The ethics of ideas and things / ed. by J. Rutherford and A. Uhlmann. New York : Bloomsbury, 2017. P. 83-103.

26. Бенвенист Э. Общая лингвистика. Москва : ЛИБРОКОМ, 2009. $448 \mathrm{c.}$

27. Tajiri Y. Beyond the Literary Theme Park: J. M. Coetzee's Late Style in The Childhood of Jesus. J. Coetzee's The Childhood of Jesus: The ethics of ideas and things / ed. by J. Rutherford and A. Uhlmann. New York : Bloomsbury, 2017. P. 187-209.

28. Coetzee JM. The Childhood of Jesus. New York : Viking, 2014. 277 p.

29. Coetzee J.M. The Schooldays of Jesus. New York : Viking, 2016. 260 p.

30. Coetzee J.M. The Death of Jesus. London : Harvill Secker, 2019. 196 p.

\section{REFERENCES}

1. Chepelieva, N. V. (2015). Tekst $i$ chytach [posibnyk] [The text and the reader: A manual]. Zhytomyr: Vyd-vo ZhDU imeni I. Franka.

2. Gridina, T. A. (2008). Yazykovaya igra v hudozhestvennom tekste [The language game in literary text] [monografiya]. Ekaterinburg: Ural. gos. ped. un-t.

3. Izotova, N. P. (2020). Linhvonaratolohiia ihrovykh khudozhnikh form: idiozhanrovyi aspekt [Linguistic narratology of ludic literary forms: An idiogenre aspect]. Visnyk $K N L U$, 23 (2), 47-57.

4. Lyuksemburg, A. M. (1999). Ambivalentnostkak svojstvo nabokovskoj igrovoj poetiki
[Ambiguity as a feature of Nabokovs ludic poetics]. Nauchno-kulturologicheskij zhurnal, 15(21). URL: http://www.relga.ru/Environ/ WebObjects/tgu-www.woa/wa/Main?textid= 1694\&level $1=$ main\&level $2=$ articles .

5. Radziievska, T. V. (2014). Movna osobystist, movna hra, linhvistychni kontsepty kriz pryzmu romanu V. V. Nabokova "The Real Life of Sebastian Knight" [Language personality, language game, linguistic concepts through the prism of V. V. Nabokovs novel "The Real Life of Sebastian Knight"]. Visnyk KNLU, 17(1), 146-155.

6. Chrzanowska-Kluczewska, E. (2004). Language games: pro and against. Krakow: Universitas.

7. Booth, W. C. (1983). The rhetoric of fiction. Chicago \& London: The University of Chicago Press.

8. Abieva, N. A. (2006). Igrovaya strategiya postroeniya narrativa $\mathrm{v}$ elektronnom hudozhestvennom tekste [The ludic strategy for building narrative in electronic fiction]. V N. D Arutyunova (Otv. red.), Logicheskij analiz yazyka. Konceptualnye polya igry (ss. 206-234). Moskva: Indrik.

9. Nikitina, E. A. (2016). Ritoricheskie priemy povestvovaniya [monografiya] [Rhetorical devices of narration]. Eleck : Izd-vo Elec. gos. univer. im. I.A. Bunina.

10. Vorozhbitova, A. A., Potapenko, S. I. (2013). Linguistic \& rhetorical paradigm as innovative theoretical methodological platform of studying discursive processes of East Slavic and Western cultures. European Researcher, 61 (10-2), 2536-2543.

11. Gejchenko, S. A. (2013). Povestvovatelnaya struktura russkogo filosofskogo teksta: lingvistika narrativa (na materiale sochinenij P. A. Florenskogo i A. F. Loseva) [The narrative structure of Russian philosophical text: A case study of the works by P. A. Florensky and A. F. Losev] (Avtoreferat kandidatskoj dissertacii). Rossijskij universitet druzhby narodov, Moskva, Rossijskaya Federaciya.

12. Bahtin, M. M. (2015). Problemy poetiki Dostoevskogo [Problems of Dostoevskys poetics]. Sankt-Peterburg: Azbuka.

13. Wilm, J. (2016). The Slow Philosophy of J. M. Coetzee. London: Bloomsbury.

14. Skorik, K. V. (2010). Dialogizaciya hudozhestvennogo teksta: tipy $i$ sposoby ee aktualizacii $v$ angloyazychnoj proze [Dialogicalization of literary text: types and ways of its manifestation in English prose]. (Avtoreferat kandidatskoj dissertacii). Sankt-Peterburgskij gosudarstvennyj universitet ekonomiki i finansov, Sankt-Peterburg, Rossijskaya Federaciya. 
15. Lagutin, V. I. (1991). Problemy analiza hudozhestvennogo dialoga [monografiya] [The problems of fictional dialogue analysis]. Kishinev : «Shtiinca».

16. Valyusinskaya, Z. V. (1979). Voprosy izucheniya dialoga $\mathrm{v}$ rabotah sovetskih lingvistov [Issues of the dialogue study in the works by Soviet linguists]. V G. A. Zolotova (Red.), Sintaksis teksta (ss. 299-313). Moskva : Nauka.

17. Lotman, Yu. M. (2015). Mekhanizmy dialoga [Dialogue mechanisms]. V Yu. M. Lotman, Vnutri myslyashchih mirov (ss. 206-219). SanktPeterburg: Azbuka, Azbuka-Attikus.

18. Girshman, M. (2007). Dialog i hudozhestvennaya celostnost [The dialogue and the artistic unity]. V M. Grishman, Literaturnoe proizvedenie: teoriya hudozhestvennoj celostnosti (2-e izd., dop.) (ss. 451-545). Moskva: Yazyki slavyanskih kultur.

19. Rutherford, J., \& Uhlmann, A. (2017). Introduction. In J. Rutherford and A. Uhlmann (Eds.), J. M. Coetzees The Childhood of Jesus: The ethics of ideas and things (pp. 3-5). New York : Bloomsbury.

20. Mehigan, T. (2017). Coetzees The Childhood of Jesus and the Moral Image of the World. In J. Rutherford \& A. Uhlmann (Eds.), J. Coetzees The Childhood of Jesus: The ethics of ideas and things (pp. 165-186). New York : Bloomsbury.

21. Hejzinga, J. (2011). Homo ludens. Chelovek igrayushchij [Homo ludens]. Sankt-Peterburg : Izd. Ivana Limbaha.
22. Soloveva, A. K. (1965). O nekotoryh obshchih voprosah dialoga [On some general issues of the dialogue]. Voprosy yazykoznaniya, 6, 104-110.

23. Longman Dictionary of Contemporary English (2005). ( $4^{\text {th }}$ ed.). London, New York: Longman.

24. Uhlmann, A. (2017). Creative Intuition: Coetzee, Plato, Bergson and Murnane. In J. Rutherford \& A. Uhlmann (Eds.), J. M. Coetzees The Childhood of Jesus (pp. 107-128). New York: Bloomsberry.

25. Rapacevich, E. S. (2006). Psihologopedagogicheskij slovar[Dictionary of psychology and education]. Minsk: Sovremennoe slovo.

26. Ng L., \& Sheehan, P. (2017). Coetzees Republic: Plato, Borges and Migrant Memory in The Childhood of Jesus. In J. Rutherford \& A. Uhlmann (Eds.), J. Coetzees The Childhood of Jesus: The ethics of ideas and things (pp. 83-103). New York : Bloomsbury.

27. Benvenist, E. (2009). Obshchaya lingvistika [General linguistics]. Moskva : LIBROKOM.

28. Tajiri, Y. (2017). Beyond the Literary Theme Park: J. M. Coetzees Late Style in The Childhood of Jesus. In J. Rutherford \& A. Uhlmann (Eds.), J. Coetzees The Childhood of Jesus: The ethics of ideas and things (pp. 187-209). New York : Bloomsbury.

29. Coetzee, J M. (2014). The Childhood of Jesus. New York : Viking.

30. Coetzee, J. M. (2016). The Schooldays of Jesus. New York : Viking.

31. Coetzee, J.M. (2019). The Death of Jesus. London : Harvill Secker. 